\title{
Insect herbivory, organic matter deposition and effects on belowground organic matter fluxes in a central European oak forest
}

\author{
Anne le Mellec • Gerhard Gerold • Beate Michalzik
}

Received: 28 July 2010 /Accepted: 21 December 2010 /Published online: 14 January 2011

(C) The Author(s) 2011. This article is published with open access at Springerlink.com

\begin{abstract}
Apart from the forest floor, the canopy of forested ecosystems functions as the second most important source for dissolved and particulate fractions of organic and inorganic $\mathrm{C}$ and $\mathrm{N}$ compounds. However, under mass outbreak situations of insect herbivores this flux path of organic matter is considerably intensified clearly exceeding $\mathrm{C}$ and $\mathrm{N}$ fluxes from the forest floor. In this paper we report on herbivore-altered $\mathrm{C}$ and $\mathrm{N}$ fluxes from the canopy to the forest floor and effects on forest floor nutrient fluxes during severe defoliating herbivory of the winter moth (Operophtera brumata) and the mottled umber moth (Eranis defoliaria) in an oak forest in Germany. Over the course of 6.5 months we followed the $\mathrm{C}$ and $\mathrm{N}$ fluxes with bulk deposition, throughfall solution, insect frass deposits (green-fall together with insect faeces) and with forest floor solution in an 117yr-old oak (Quercus petraea) forest. Compared to the
\end{abstract}

Responsible Editor: Gerlinde De Deyn.

A. le Mellec $(\bowtie) \cdot$ G. Gerold

Landscape Ecology Section, Institute of Geography, University of Göttingen,

Goldschmidtstr. 5,

37077 Göttingen, Germany

e-mail: amellec@gwdg.de

B. Michalzik

Institute of Geography, Friedrich-Schiller-University Jena,

Löbdergraben 32 ,

07743 Jena, Germany control, herbivore defoliation significantly enhanced throughfall inputs of total and dissolved organic carbon and nitrogen by a factor of 3 and 2.5 (for TOC and DOC), and by 1.4 and 1.3 times (for $\mathrm{TNb}$ and $\mathrm{DNb}$ ), respectively. Frass plus green-fall $\mathrm{C}$ and $\mathrm{N}$ fluxes peaked in May with $592 \mathrm{~kg} \mathrm{Cha}^{-1}$ and $33.5 \mathrm{~kg} \mathrm{Nha}^{-1}$ representing $79.6 \%$ (for $\mathrm{C}$ ) and $78.3 \%$ (for $\mathrm{N}$ ) of the total $\mathrm{C}$ and $\mathrm{N}$ input over 2.5 months. The quantitative and qualitative $\mathrm{C}$ and $\mathrm{N}$ input via faeces and litter deposition significantly differ between the insect affected and non-affected site. However, the $\mathrm{C}$ and $\mathrm{N}$ fluxes with throughfall did not significantly correlate with forest floor leachates. In this context, forest floor fluxes of TOC, DOC and $\mathrm{NO}_{3}-\mathrm{N}$ were significantly lower at the infested site compared to the control, whereas fluxes of $\mathrm{NH}_{4}-\mathrm{N}$ together with DON were significantly higher. The study demonstrates the importance of linking the population and associated frass dynamics of herbivorous insects with the cycling of nutrients and organic matter in forest ecosystems, highlighting the remarkable alterations in the timing, amounts and nature of organic matter dynamics on the ecosystem level. Consequently, the ecology of phytophagous insects allows partly to explain temporal-spatial alterations in nutrient cycling and thus ecosystem functioning.

Keywords Insect mass outbreaks · Organic matter fluxes · Oak forest 


\section{Introduction}

Natural disturbances like insect mass outbreaks are regarded as important drivers for ecosystem processes, and furthermore for the development and maintenance of forested landscapes. As biotic agent, insect pests can achieve a far-reaching importance for forest functioning and ecosystem services especially under epidemic conditions. For example, herbivorous insects can function as a regulator of forest primary productivity and may lead to an increase in aboveground biodiversity after defoliation (Fonte and Schowalter 2004; Hartley and Jones 2004).

On the other hand, severe defoliation caused by insect pests can have a considerable impact on the forestry sector by reducing tree growth and timber quality leading to an economic loss of woody products (Jactel et al. 2009; Dale et al. 2001; Långström et al. 2001). Heavy mass outbreaks can have the potential to alter natural forested landscapes and habitat structure by extinguishing tree species and associated fauna and flora (Parmesan and Yohe 2003; Brändle and Brandl 2001). Hence, insect pests can influence the health of forests positively or negatively through direct and indirect effects mainly driven by the frequency, severity and spatial extent of the mass outbreak events.

To maintain ecosystem services and functions, which are seriously pertubated by insect mass outbreaks, many efforts have been made to understand the interplay between host tree, insect ecology and biotic and abiotic drivers (Schwenke 1962; Cedervind et al. 2003; Huberty and Denno 2004; Mattson and Haack 1987; Långström and Hellqvist 1993; Annila et al. 1999; Larsson and Tenow 1984).

Hence, various studies have demonstrated that mass outbreaks of insects can also have strong effects on the organism and biogeochemical scale. Hunter (2001) determined seven broad mechanisms by which insect herbivores activity has the potential to alter nutrient cycling and availability in soils. For example, insect herbivores affect the recycling of nutrients directly by their deposits (faeces) and cadavers. Indirectly by the enhanced nutrient content within the throughfall solution of infested trees, by altered chemical composition of infested leaf deposition onto the soil, altered composition of herbaceous soil vegetation and plant community, and by frass induced changes of root exudates which consequently affect soil microbial activity and community patterns. Finally, insect pests can shift the soil microclimate due to changes in the canopy cover creating increased light penetration and differences in water cycling.

Herbivorous insects are able to transform needle biomass or leaf constituents into more easily degradable secondary products (e.g. insect pellets, honeydew) (Chapman et al. 2003; Hunter 2001; Schowalter et al. 1991; Stadler et al. 2001). Through this transformation, herbivorous insects may promote mineralisation activity, leading to accelerated decomposition rates and hence to an intensified release of nutrients and carbon (Ritchie et al. 1998; Chapman et al. 2003; Lovett and Ruesink 1995; Stadler et al. 2001; le Mellec et al. 2009). How strongly insect mass attacks can impact forest stands on the ecosystem level was demonstrated by the study of Kurz et al. (2008), where the devastation of millions of hectares by a bark beetle infestation led to an enormous increase of $\mathrm{CO}_{2}$ emissions during the growing season.

Regarding the tree canopy as a habitat for insects and microorganism (food source, livelihood) at the interface between the atmosphere (external) and the plant biosphere (internal tree metabolism), the canopy can be considered as the second largest source for dissolved organic matter. Annual inputs of DOC by throughfall amounted to $40-160 \mathrm{~kg} \mathrm{Cha}^{-1}$ (Bergvist and Folkeson 1992; Qualls and Haines 1991). Corresponding inputs of $\mathrm{N}$ species range between 1.2-11.5 kg DON ha ${ }^{-1}, 0.5-16.8 \mathrm{~kg} \mathrm{NO}_{3}-\mathrm{N} \mathrm{ha}^{-1}$ and $0.3-46 \mathrm{~kg} \mathrm{NH}_{4}-\mathrm{N} \mathrm{ha}^{-1}$, respectively (Piirainen et al. 1998; Qualls and Haines 1991; Michalzik et al. 2001; Gauger et al. 2008). Nevertheless, organic matter input with throughfall has been often neglected in element cycling as it contributes only to a smaller proportion to the vertical transport of matter and energy as compared for example to the input of $\mathrm{C}$ and $\mathrm{N}$ by leaf litter (900-2,600 $\mathrm{kg} \mathrm{Cha}^{-1} \mathrm{a}^{-1}, 20-55 \mathrm{~kg} \mathrm{~N}$ $\mathrm{ha}^{-1} \mathrm{a}^{-1}$ ) (Michalzik et al. 2001).

However, under insect mass outbreak situation the function of tree canopies as source for organic matter and nutrients increases considerably. In this context, a previous study in a pine forest stand in Germany demonstrated remarkable effects of the defoliation activity of the pine lappet moth (Dendrolimus pini) causing a magnified transfer of organic matter from the canopy to the soil. Inputs of organic carbon to the forest floor amounted to $180 \mathrm{~kg} \mathrm{Cha}^{-1} 6$ months $^{-1}$ 
(by throughfall) and up to $520 \mathrm{~kg} \mathrm{Cha}^{-1} 6$ months $^{-1}$ (by frass and green-leaf deposition) during the growing season (le Mellec and Michalzik 2008).

In general, it appeared that herbivorous activities under epidemic conditions lead to alterations in nutrient cycling through quantitatively and qualitatively changed organic matter fluxes to the forest floor (le Mellec and Michalzik 2008; le Mellec et al. 2009). In this context, it is suggested that DOM input with throughfall is a leading promoter for decomposition processes in the forest floor, significantly affecting the $\mathrm{C}$ partitioning of the litter input into $\mathrm{CO}_{2}, \mathrm{DOC}$ and humic material and its fate in the mineral soil (Madritch and Hunter 2003; Chapman et al. 2003: Frost and Hunter 2004).

Only a few field studies followed the pathway and composition of insect-mediated organic matter fluxes from the canopy into the mineral soil and the effects on organic matter cycling in the soil. However, the determination of driving factors-like biological agents - governing nutrient fluxes and fluctuations in different ecosystem strata, might partly explain the sudden occurrence of temporal-spatial alterations in nutrient cycling and thus ecosystem functioning (Schowalter 2000; Wardle et al. 2000; Michalzik and Stadler 2005).

Addressing this aspect, we investigated the shortterm effects of a mass outbreak of the winter moth (Operophtera brumata) and the mottled umber moth (Eranis defoliaria) in an oak forest on the above and belowground fluxes of organic matter and associated fractions of C and N. In detail, three hypotheses were tested: mass outbreak situations affect (a) the above and belowground $\mathrm{C}$ and $\mathrm{N}$ matter release, where the canopy is more directly and more intensively affected than the forest floor, (b) the production and proportion of the particulate $\mathrm{C}$ and $\mathrm{N}$ fractions in the two compartments, and (c) the production of residual- $\mathrm{N}$ $\left(\mathrm{NH}_{4}-\mathrm{N}\right.$ and $\left.\mathrm{DON}\right)$ in canopy and forest floor solutions.

\section{Material and methods}

Study area

The study was carried out from the beginning of April to mid-October 2006 in the "Rotenburg" region located in the north-eastern part of Germany in Lower
Saxony between Bremen, Hannover and Hamburg. The study area is embedded in a moraine landscape, with a mean annual precipitation of approximately 650-700 $\mathrm{mm}$ and mean annual temperatures of approximately $8.6^{\circ} \mathrm{C}$ (German Federal Meteorological Service, Frankfurt/Main).

We quantified the temporal dynamics of $\mathrm{C}$ and $\mathrm{N}$ inputs with throughfall and with insect frass as well as the amount and composition of soil leachates of two oak forest sites (Quercus petraea) in the "Trocheler Forst", where one site was heavily infested by a mass outbreak of the winter moth (Operophtera brumata) and the mottled umber moth (Eranis defoliaria), whereas the other one served as an un-infested control stand.

The two sites covered similar areas of about 10.7 and 12.2 ha and exhibited resembling structural and environmental factors. The soil type was classified as a Stagnic Luvisol (FAO classification) derived from glacial and aeolian sand and loess deposits, covered by a moder-like humus type. Both sites exhibited an approximately 117 year-old oak stand with a stand density of 0.8 and 0.9 , respectively.

The initial density of the female moths was estimated by tree paste-ring analysis. This was done within the pest-monitoring programme of the Northwest German Forest Research Station (NW-FVA). The critical threshold value of $>1$ adult female per $\mathrm{cm}^{2}$ trunk size was clearly exceeded with seven to ten individuals indicating a forthcoming heavy mass outbreak. The level of defoliation in 2006 at the oak site was classified between $60 \%$ to $70 \%$ loss of the leaf biomass (NW-FVA). With regard to the population ecology of the two moth species, our study was conducted in the 3 rd year of the progradation phase which was followed by peaking insect numbers (for both, the winter and the mottled umber moth) during culmination in 2006 (NW-FVA). The frass activity of the winter moth as well as the mottled umber moth occurred within a short time frame starting with the leave shoot in mid-May till the end of July. Our observations were accompanied by the pestmonitoring activities of the Northwest Forest Research station (NW-FVA).

Field experiment

The experimental set-up at the two forest sites consisted of ten randomly established throughfall 
samplers (20 cm diameter) each. For analysis, ten throughfall samples per experimental plot and sampling date were pooled to five mixed samples. To quantify the atmospheric element deposition (bulk), two rain samplers were installed at an open field nearby.

Additionally, three zero-tension humus lysimeter per site were installed underneath the Oa layer. Sampling of the throughfall and forest floor solutions was performed by 7 day and 14 day intervals during emerging and peaking infestation levels from April to mid-July and later on in 4-week intervals till midOctober 2006.

The quantification of the amounts of (green) litter fall and insect derived fragments (faeces, leaf debris) were done with the help of six nylon tree nets with $n=$ 3 per study site. The mesh size of the net material was 300 by $300 \mu \mathrm{m}$. One single net was stretched around one oak tree and was individually adjusted to the canopy diameter resulting in differing net areas of 13.56, 14.27 and $13.78 \mathrm{~m}^{2}$ at the infested site and $13.89,14.01$ and $13.28 \mathrm{~m}^{2}$ at the un-infested site. The sampling of solid matter inputs were performed in 7 day and 14 day intervals from mid May till the end of July, in correspondence to the frass activity of the larvae.

\section{Chemical analysis}

One aliquot each of the bulk and throughfall solutions and the soil leachates was $0.45-\mu \mathrm{m}$ membrane-filtered (Cellulose-acetate filters, Sartorius) representing the dissolved fraction of organic matter. The chemical analysis included the determination of dissolved organic carbon (DOC) and dissolved nitrogen bound $(\mathrm{DNb})$ by thermal oxidation (Dimatoc 100, Dimatec, Essen, Germany), and $\mathrm{NO}_{3}{ }^{-}$by ion chromatography (761 Compact IC, Metrohm). From the difference between $\mathrm{DNb}$ and $\mathrm{NO}_{3}-\mathrm{N}$ we calculated "residual-N" consisting of $\mathrm{NH}_{4}-\mathrm{N}$ and dissolved organic nitrogen (DON).

In unfiltered aliquots, total organic carbon and total nitrogen bound (TOC and $\mathrm{TNb}$, particle size between $0.45 \mu \mathrm{m}$ and $500 \mu \mathrm{m}$ ) were also assessed by thermal oxidation (Dimatoc 100, Dimatec, Essen, Germany), where the upper particle size limit of $500 \mu \mathrm{m}$ was given operationally by the capillary diameter of the TOC/TN-analyser. Particulate organic carbon (POC) was calculated as difference between TOC and DOC, and particulate organic nitrogen $(\mathrm{PNb})$ as difference between $\mathrm{TNb}$ and $\mathrm{DNb}$. Element fluxes were calculated from measured water volumes and element concentrations.

For determining the solid matter input at the two sites, tree net inputs were weighed, dried at $45^{\circ} \mathrm{C}$, and then analysed for $\mathrm{C}$ and $\mathrm{N}$ contents. In this context, the solid matter input at the control site mainly consisted of leaf litter material, whereas solid matter input at the infested site was predominately insect digested leaf material (insect faeces). $\mathrm{C}$ and $\mathrm{N}$ analysis were done for leaf litter and insect faeces by thermal oxidation (Leco CHN 1000). The input fluxes of $\mathrm{C}$ and $\mathrm{N}$ with insect faeces and litter were calculated from dry matter weights and corresponding $\mathrm{C}$ and $\mathrm{N}$ contents.

\section{Statistical analysis}

Our statistical analyses obtained tests for significant differences between infested and un-infested throughfall and soil fluxes as well as for significant correlations between above and belowground matter fluxes.

\section{Test for significant differences}

We chose two statistical software programs to test for differences in fluxes of throughfall as well as soil percolates gathered from the infested and un-infested site.

Due to the fact that we were not able to provide spatial replications of the infested study area, we tested the statistical differences of the same data by two statistical approaches: First, by the randomized intervention analysis (RIA) by the statistical software $\mathrm{R}$ (The R Foundation for Statistical Computing), which is a reliable method to test significant changes in manipulated ecosystems before and after an impact occurrence compared to an un-impacted control site. Second, by the Mann-Whitney- $U$ test for nonnormally distributed data from IBM SPSS statistics (SPSS) including the tests for independent variables. Both analyses achieved the same results. In the results section, statistical data of the RIA test were presented.

\section{Correlation analysis}

The correlations were carried out by Spearman correlation analysis for non-normally distributed data with help of the software Statistika 9 (StatSoft). 


\section{Results}

In general, severe mass outbreaks of defoliating insects turn the canopy into the biggest source for dissolved and particulate $\mathrm{C}$ and $\mathrm{N}$ compounds distinctly exceeding the organic matter release from the forest floor. With the exception of $\mathrm{NO}_{3}-\mathrm{N}$, throughfall fluxes of all observed $\mathrm{C}$ and $\mathrm{N}$ fractions clearly surpassed those with forest floor solutions (Table 1). Especially the input situation of the "residual-"N complex consisting of DON and ammonium appeared to be enhanced under pest conditions compared to the control site. However, under non-infestation, the forest floor exhibited higher fluxes of nearly all $\mathrm{C}$ and $\mathrm{N}$ fractions, except for POC and "residual-"N (Table 1).

\section{Canopy-to-soil transfer}

Compared to the control, the infested site exhibited significantly higher fluxes of $\mathrm{C}$ and $\mathrm{N}$ fractions with throughfall solution, with the exception of $\mathrm{NO}_{3}-\mathrm{N}$ being significantly higher at the un-infested site (Table 1).

Table 1 shows the accumulated TOC fluxes over 6.5 months at the infested site and at the control site (Table 1) and corresponding fluxes of total $\mathrm{N}$ fluxes. Peak fluxes of DOC, $\mathrm{POC}, \mathrm{DNb}$ and $\mathrm{PNb}$ were observed during mid/end of May, with the dissolved fractions yielding the highest flux amounts exhibiting approximately $7,000 \mathrm{mg} \mathrm{m}^{-2}$ or $70 \mathrm{~kg} \mathrm{DOC} \mathrm{ha}^{-1}$ and $600 \mathrm{mg} \mathrm{m}^{-2}$ or $6 \mathrm{~kg} \mathrm{DNb} \mathrm{ha}^{-1}$ (Figs. 1 and 2). In general, herbivore defoliation significantly enhanced throughfall inputs of total, dissolved and particulate organic carbon and nitrogen by a factor of 3, 2.5 and 5.2 (for TOC, DOC, POC), and by 1.4, 1.3 and 1.9 times (for $\mathrm{TNb}, \mathrm{DNb}, \mathrm{PNb}$ ) compared to the control. However, $\mathrm{NO}_{3}-\mathrm{N}$ in throughfall solution was significantly diminished under insect infestation (Table 1). Regarding the composition of dissolved N, fluxes of residual-N encompassing $\mathrm{NH}_{4}-\mathrm{N}$ and DON represented $92 \%$ of $\mathrm{DNb}$ under infestation, compared to $87 \%$ at the control site.

Herbivory also magnified the flux proportions of the particulate fractions relative to the total fluxes of elements. In this context, the amount of $\mathrm{PNb}$ relative to $\mathrm{TNb}$ was $30.4 \%$ at the infested and $23 \%$ at the uninfested site. Corresponding values for POC and TOC were $30.1 \%$ and $17.4 \%$, respectively. In general, differences between the infested and control site differed significantly $(p<0.05)$ from each other.

Forest floor percolates

Aboveground fluxes of $\mathrm{C}$ and $\mathrm{N}$ fractions (DOC, $\mathrm{POC}, \mathrm{DNb}, \mathrm{PNb}$ ) appeared to be decoupled from $\mathrm{C}$
Table 1 Accumulated fluxes $\left(\mathrm{kg} \mathrm{ha}^{-1}\right)$ over 6.5 months of different $\mathrm{C}$ and $\mathrm{N}$ fractions in throughfall solution and forest floor leachates at the infested and un-infested oak site

TOC total organic carbon, $D O C$ dissolved organic carbon, $P O C$ particulate organic carbon, $T N b$ total nitrogen bound, $\mathrm{DNb}$ dissolved nitrogen bound, $P N b$ particulate nitrogen bound; Residual-N = dissolved organic nitrogen + ammonium. Level of significance $(* p<0.05 / * * p<0.01, * * * p<$ 0.001 ), indicating differences between infested vs. uninfested tested by random intervention analysis (RIA)

\begin{tabular}{lccc}
\hline C and N fractions & Infested kg ha ${ }^{-1}$ time $^{-1}$ & Un-infested $\mathrm{kg} \mathrm{ha}^{-1}$ time $^{-1}$ & Open field $\mathrm{kg} \mathrm{ha}^{-1} \mathrm{time}^{-1}$ \\
\hline Throughfall & & & \\
TOC & $238.1^{* * *}$ & 79.5 & 32.5 \\
DOC & $166.4^{* * *}$ & 65.7 & 26.7 \\
POC & $71.7^{* * *}$ & 13.8 & 5.8 \\
TNb & $32.5^{*}$ & 22.6 & 13.6 \\
DNb & $22.7^{*}$ & 17.5 & 12.9 \\
PNb & $9.9^{*}$ & 5.2 & 0.7 \\
Nitrate-N & 1.8 & $2.2^{*}$ & 2.2 \\
Residual-N & $20.9^{*}$ & 15.3 & 10.7 \\
Forest floor $(\mathrm{Oa})$ & & & no sampling \\
TOC & 105.1 & $117.1^{*}$ & - \\
DOC & 95.9 & $111.9^{*}$ & - \\
POC & $9.2^{*}$ & 5.1 & - \\
TNb & 29.4 & 27.9 & - \\
DNb & 28.2 & 26.7 & - \\
PNb & 1.2 & 1.3 & - \\
Nitrate-N & 14.8 & $17.0^{*}$ & - \\
Residual-N & $13.4^{*}$ & 9.7 & - \\
\hline & & & -
\end{tabular}



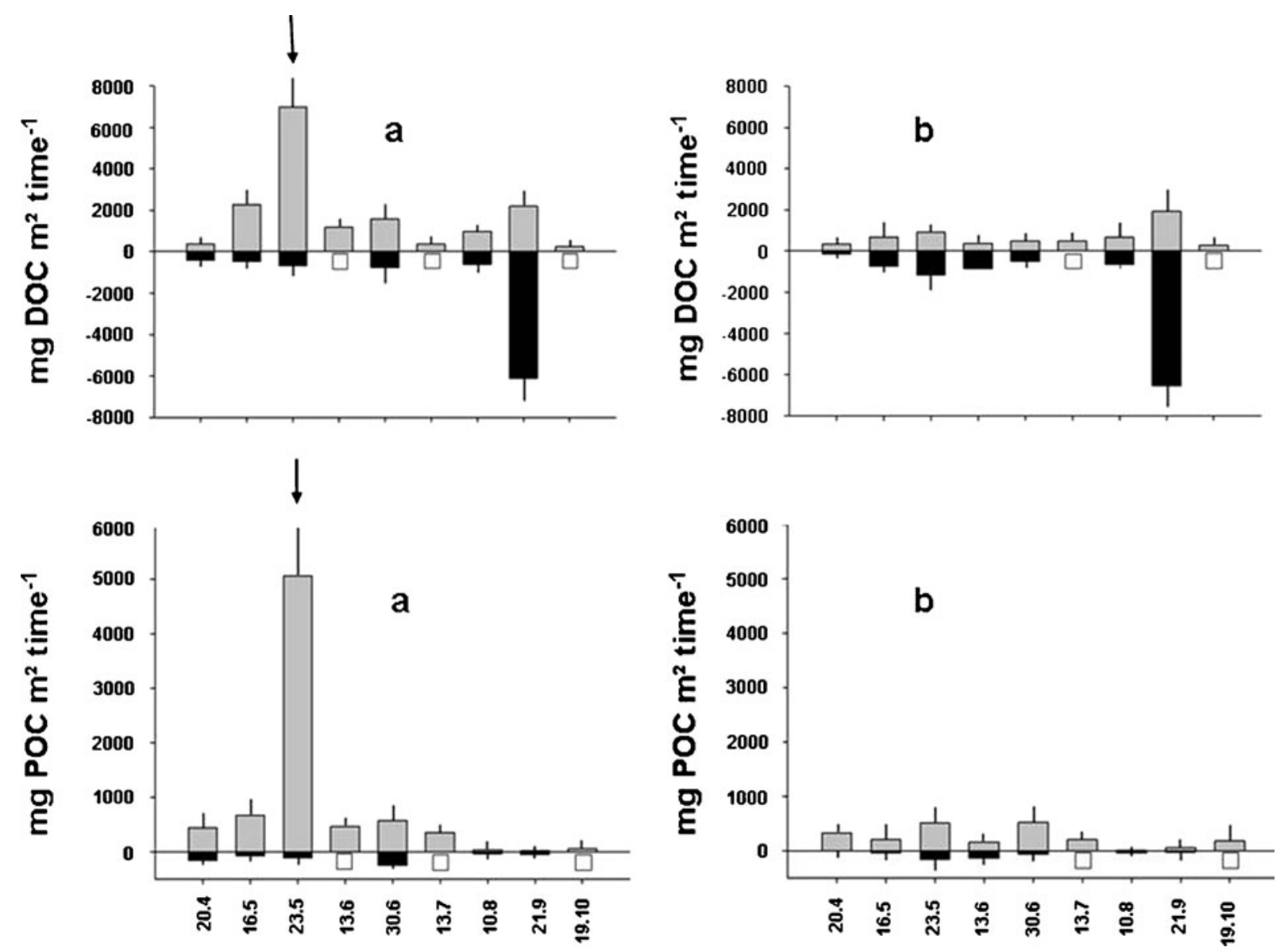

Fig. 1 Fluxes of dissolved and particulate carbon with throughfall (grey columns) and forest floor (black columns) solution at the infested (a) and un-infested (b) oak site. The

and $\mathrm{N}$ dynamics in the forest floor, since there was no significant correspondence between the temporal flux dynamics of $\mathrm{C}$ and $\mathrm{N}$ in throughfall and forest floor percolates notable, neither at the infested nor at the control site (Figs. 1 and 2). However, high output fluxes of dissolved $\mathrm{C}$ and $\mathrm{N}$ from the Oa layer were reported 4 months later for September 21st amounting to $60 \mathrm{~kg} \mathrm{DOC} \mathrm{ha}{ }^{-1}$ and $23 \mathrm{~kg} \mathrm{DNb} \mathrm{ha}{ }^{-1}$ at the infested site. Those peak fluxes did not occur in case of the particulate fractions of $\mathrm{C}$ and $\mathrm{N}$ (Figs. 1 and 2).

At both sites, $\mathrm{DNb}$ was dominantly represented by $\mathrm{NO}_{3}-\mathrm{N}(52 \%$ of $\mathrm{DNb}$ at the infested and $64 \%$ uninfested site, Table 1). Nitrate-N fluxes from the uninfested forest floor were significantly higher (by 13\%) compared to the infested site, whereas fluxes of residual-N were significantly lower (by 27\%) (Table 1).

arrow indicates the strongest defoliating activity. Blank columns indicate dates, where no soil solutions were available

Particulate organic $\mathrm{C}$ in forest floor percolates amounted to $9 \%$ of TOC at the infested compared to $4 \%$ at the control site (Table 1). Proportions of $\mathrm{PNb}$ in $\mathrm{TNb}$ were similar at both sites exhibiting values of about $4 \%$.

With regard to $\mathrm{C}$ and $\mathrm{N}$ composition, canopyderived fractions of $\mathrm{C}$ and $\mathrm{N}$ consisted of remarkably higher proportions of particulate compounds in total $\mathrm{C}$ and $\mathrm{N}$ than solutions from the forest floor. For POC, these effects were found to be most amplified under insect herbivory (Table 1). The same was shown for the fraction of residual-N in $\mathrm{DNb}(48 \%$ and $36 \%$, respectively).

At both sites, there were no significant correlations between the precipitation amounts and the $\mathrm{C}$ and $\mathrm{N}$ fluxes with throughfall found (data not shown) exhibiting element dynamics independent from flux hydrology. 


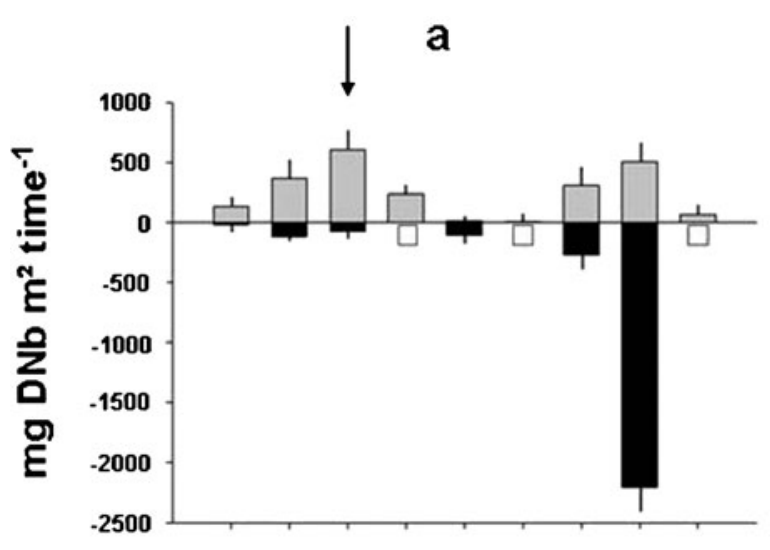

b
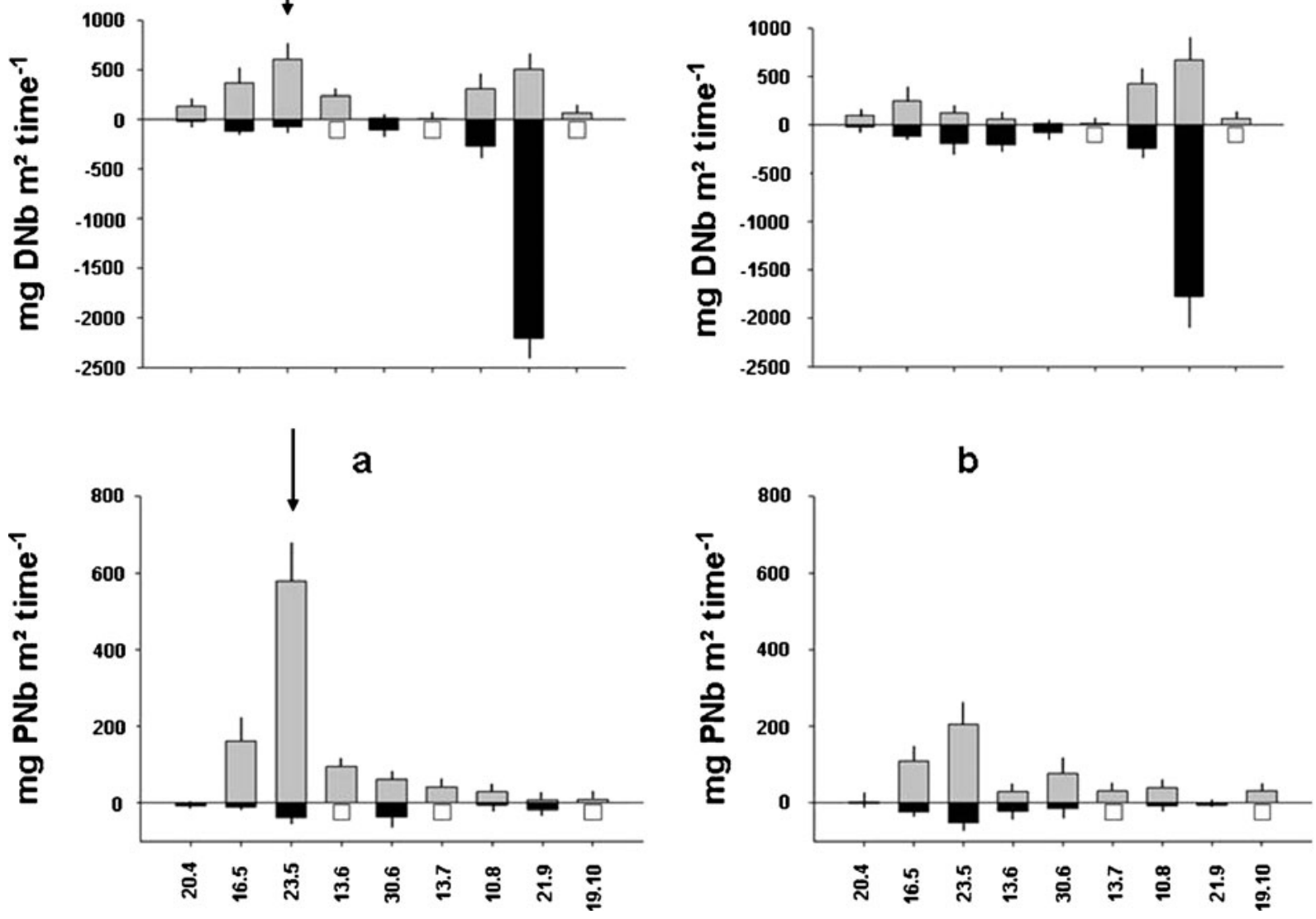

Fig. 2 Fluxes of dissolved and particulate nitrogen with throughfall (grey columns) and forest floor (black columns) solution at the infested (a) and un-infested (b) oak site. The

However, the volumes of soil percolates were slightly significantly correlated with TOC and $\mathrm{TNb}$ fluxes from the forest floor at both study sites $(r=0.763, P=0.05$ for $\mathrm{TOC}$ and $\mathrm{TNb}$ )

\section{Solid matter input}

Table 2 shows the $\mathrm{C}$ and $\mathrm{N}$ input by dry deposits encompassing insect faeces and litter. The total frass input of $742 \mathrm{~kg} \mathrm{Cha}^{-1}$ was mainly composed by insect faeces $(71 \%)$ and to a minor extend by leaf litter (29\%). Corresponding values for $\mathrm{N}$ were $76.6 \%$ by insect faeces and the rest by litter. At the control site with endemic levels of infestation, the total $\mathrm{C}$ input was $9 \mathrm{~kg} \mathrm{ha}^{-1}$ with a contribution of faecesderived $\mathrm{C}$ of $3.4 \mathrm{~kg} \mathrm{ha}^{-1}$ (or $38 \%$ ) and the mayor arrow indicates the strongest defoliating activity. Blank columns indicate dates, where no soil solutions were available

proportion presented by litter $\left(5.6 \mathrm{~kg} \mathrm{Cha}^{-1}\right)$ (Table 2). The input fluxes of $\mathrm{N}$ were $0.4 \mathrm{~kg} \mathrm{Nha}^{-1}$ with half of the $\mathrm{N}$ originating from faeces and half from litter material.

The temporal development of frass amount and composition is given in Fig. $3 \mathrm{a}$ and b. Under herbivory, the largest increase in faeces and litterderived $\mathrm{C}$ and $\mathrm{N}$ input became notable in mid-May. Within 1 week $40.2 \mathrm{gm}^{-2}$ or $400 \mathrm{~kg} \mathrm{Cha}^{-1}$ and $24.4 \mathrm{~kg} \mathrm{Nha}^{-1}$ were deposited with faeces material and $188.9 \mathrm{~kg} \mathrm{Cha}^{-1}$ and $9.1 \mathrm{~kg} \mathrm{Nha}^{-1}$ with leaf litter. During this short time period, $79.6 \%$ and $78.3 \%$ of the $\mathrm{C}$ and $\mathrm{N}$ input with solid matter already entered the ground.

Subsequent to the peaking frass activity in mid/end of May, the $\mathrm{C} / \mathrm{N}$ ratio between the litter and the faeces 
Table 2 Insect-derived total $\mathrm{C}$ and $\mathrm{N}$ input (litter vs. insect faeces) $\left(\mathrm{kg} \mathrm{ha}^{-1}\right)$ over 2.5 months at the infested and un-infested (control) oak site

\begin{tabular}{|c|c|c|c|c|c|c|c|}
\hline \multicolumn{5}{|c|}{ Infested site } & \multicolumn{3}{|c|}{ Control site } \\
\hline $\begin{array}{l}\text { Litter C } \\
\mathrm{kg} \mathrm{ha}^{-1}\end{array}$ & $\begin{array}{l}\text { Litter N } \\
\mathrm{kg} \mathrm{ha}^{-1}\end{array}$ & $\begin{array}{l}\text { Faeces C } \\
\mathrm{kg} \mathrm{ha}^{-1}\end{array}$ & $\begin{array}{l}\text { Faeces N } \\
\mathrm{kg} \mathrm{ha}^{-1}\end{array}$ & $\begin{array}{l}\text { Litter C } \\
\mathrm{kg} \mathrm{ha}^{-1}\end{array}$ & $\begin{array}{l}\text { Litter N } \\
\mathrm{kg} \mathrm{ha}^{-1}\end{array}$ & $\begin{array}{l}\text { Faeces C } \\
\mathrm{kg} \mathrm{ha}^{-1}\end{array}$ & $\begin{array}{l}\text { Faeces N } \\
\mathrm{kg} \mathrm{ha}^{-1}\end{array}$ \\
\hline $214.4^{* * *}$ & $10.0 * * *$ & $528.4 * * *$ & $32.8 * * *$ & 5.6 & 0.2 & 3.4 & 0.2 \\
\hline
\end{tabular}

Level of significance $(* p<0.05, * * p<0.01, * * * p<0.001)$, indicating differences between infested vs. uninfested $\mathrm{C}$ and $\mathrm{N}$ input by insect faces and litter tested by random intervention analysis (RIA)
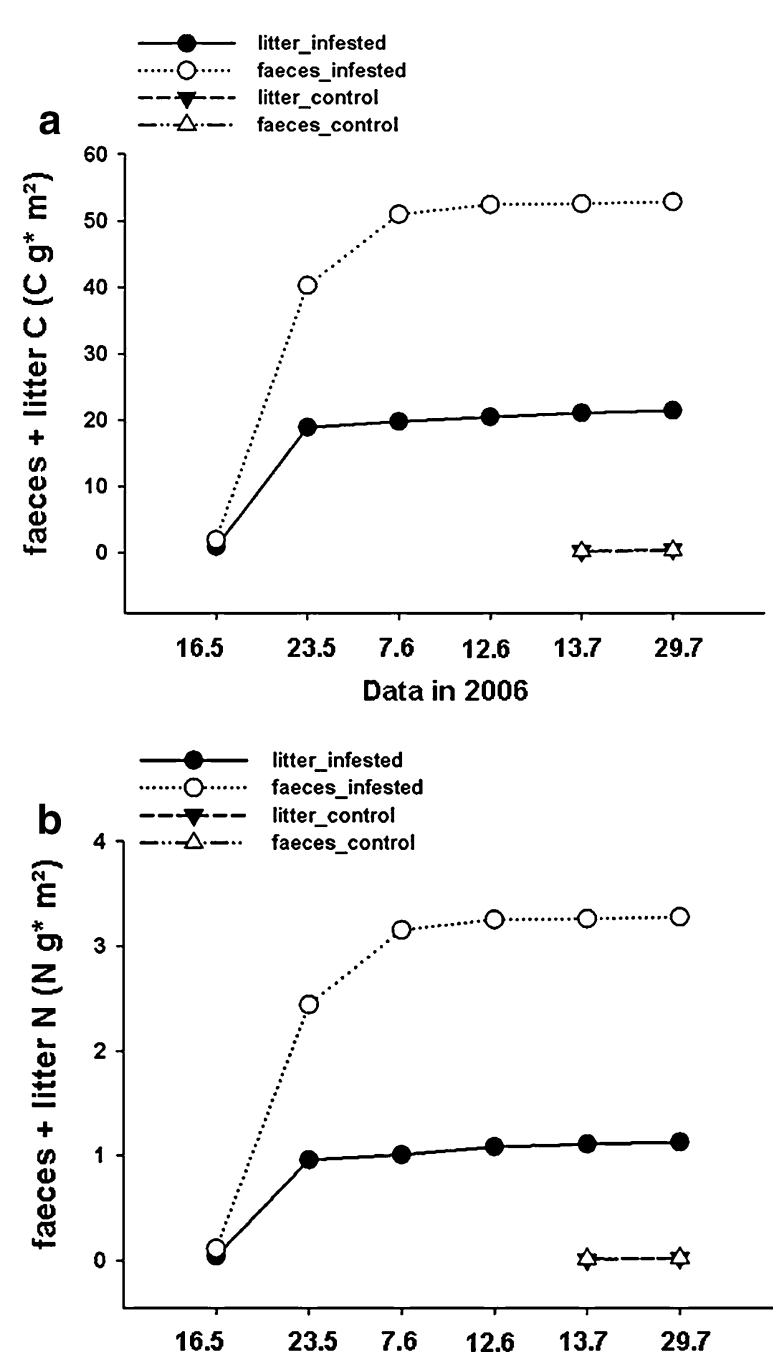

Fig. 3 a Cumulative fluxes of insect faeces and litter $C$ under insect outbreak and control conditions. b Cumulative fluxes of insect faeces and litter $\mathrm{N}$ under insect outbreak and control conditions material appeared to differ significantly with lower values between 16 and 18 in the faeces material and significantly higher values of around 23 in fallen leaf litter (Fig. 4).

\section{Discussion}

In this study we investigated the effects of mass outbreaks of herbivorous insects on the $\mathrm{C}$ and $\mathrm{N}$ release from above (canopy) and belowground (forest floor) compartments in a Central European oak stand in Germany.

We hypothesised that insect mass outbreak situations affect (a) the above and belowground $\mathrm{C}$ and $\mathrm{N}$ matter release, where the canopy is more directly and more intensively affected than the forest floor, (b) the production and proportion of the particulate $\mathrm{C}$ and $\mathrm{N}$ fractions in the two compartments, and (c) the

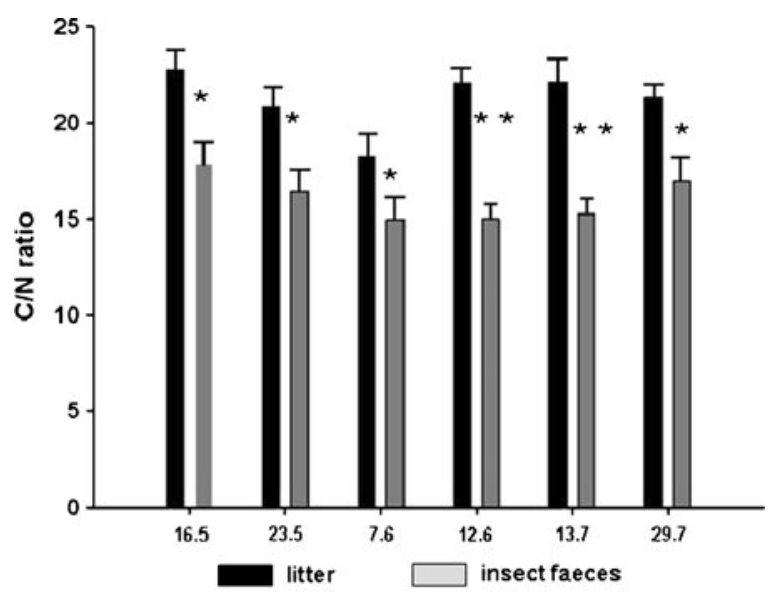

Fig. $4 \mathrm{C} / \mathrm{N}$ ratio of leaf-litter and insect faeces at the infested site, Level of significance $(* p<0.05, * * p<0.01, * * * p<0.001)$, indicating differences between litter and faeces $\mathrm{C} / \mathrm{N}$ ratios 
production of residual-N $\left(\mathrm{NH}_{4}-\mathrm{N}\right.$ and $\left.\mathrm{DON}\right)$ in canopy and forest floor solutions.

Our results elucidated that the canopy of forested ecosystems plays an important role for the release of dissolved and particulate $\mathrm{C}$ and $\mathrm{N}$ compounds even under endemic levels of infestation. However, under heavy infestation of defoliating insects, the canopy temporarily became the biggest source for all $\mathrm{C}$ and $\mathrm{N}$ compounds (Figs. 1 und 2) within the ecosystem, except for nitrate pointing to a temporal sink for inorganic $\mathrm{N}$ species within the phyllosphere. This corroborates findings by Stadler et al. (1998 and 2001), who hypothesised that changes in the quality of throughfall chemistry under canopy herbivory supply evidence for the trophic interaction with phyllosphere micro-organisms immobilizing $\mathrm{N}$ in the canopy. In this case, the lowered proportions of $\mathrm{NO}_{3}{ }^{-}$ $\mathrm{N}$ in $\mathrm{DNb}$ during highest feeding activity relative to the control site can probably be attributed to an enhanced biomass growth of phyllosphere microorganisms (filamentous fungi, bacteria, yeasts) immobilizing inorganic $\mathrm{N}$ in the presence of easily available $\mathrm{C}$ compounds released from frass-damaged leaves.

In this context, we assume that the role of canopies with regard to $\mathrm{N}$ immobilization and transformation is not fully understood. With respect to the direct annual uptake of $4 \mathrm{~kg} \mathrm{Nha}^{-1}$ by gaseous $\mathrm{N}$-species in form of $\mathrm{NH}_{3}$ and $\mathrm{NO}_{2}$ (Kreutzer et al. 2009), canopies seem to play a more important role than supposed by acting as a $\mathrm{N}$ sink and transformer of inorganic $\mathrm{N}\left(\mathrm{NO}_{3}-\mathrm{N}\right.$, $\mathrm{NH}_{4}-\mathrm{N}$ ) into organic $\mathrm{N}$-species through microbial $\mathrm{N}$ immobilization, transformation and release. Hence, the enhanced growth and likely accelerated turn-over of phyllosphere microbial biomass promoted by easily available $\mathrm{C}$ and inorganic $\mathrm{N}$ under herbivore infestation (Lovett et al. 2002), likely contribute to the intensified release of "residual-N" (DON and $\mathrm{NH}_{4}-\mathrm{N}$ ) and of POC and PNb $(>0.45 \mu \mathrm{m})$ as well. Hence, beside a direct quantitative alteration in organic matter fluxes, the insect-induced frass activity also creates qualitative changes from inorganic to more organic $\mathrm{N}$ dominated matter fluxes.

Throughfall composition at the infested sites clearly revealed patterns of associated herbivore excretion activity in both, the dissolved and total (particulate) $\mathrm{C}$ and $\mathrm{N}$ fractions, whereas the control sites remained mostly unaffected, always exhibiting smaller fluxes. In this context, le Mellec and
Michalzik (2008) report on a significant contribution of particulate organic $\mathrm{N}$ and $\mathrm{C}$ providing an extra input of up to $60 \%$ to the dissolved $\mathrm{N}$ and up to $30 \%$ to the dissolved $\mathrm{C}$ fluxes with throughfall during a mass outbreak of the pine lappet. Furthermore, it appears, that POM fluxes with throughfall likely serve as an early indicator for leaf feeding activity in forest canopies (le Mellec et al. 2009).

Herbivory affected the amount and composition of $\mathrm{C}$ and $\mathrm{N}$ in throughfall more directly and distinctly than in forest floor solutions. While the temporal variability of frass-induced $\mathrm{C}$ and $\mathrm{N}$ deposition was directly echoed by the element fluxes with throughfall, opposite flux pattern were notable in forest floor solutions. The $\mathrm{C}$ and $\mathrm{N}$ fluxes with throughfall did not significantly correlate with forest floor leachate fluxes. Consequently, it appeared that the biotically mediated above-ground fluxes of $\mathrm{C}$ and $\mathrm{N}$ were mostly decoupled from the belowground $\mathrm{C}$ and $\mathrm{N}$ dynamics. In this context, forest floor fluxes of TOC, DOC and $\mathrm{NO}_{3}-\mathrm{N}$ were significantly lower at the infested site compared to the control, whereas fluxes of $\mathrm{NH}_{4}-\mathrm{N}$ together with DON were significantly higher. Nevertheless, the reasons behind the observed diverting response patterns of the soil system are not clear, likely encompassing altered soil microbial activity resulting in an immobilisation of $\mathrm{NO}_{3}-\mathrm{N}$ and the formation of organic $\mathrm{N}$ accompanied by a possibly higher production of $\mathrm{CO}_{2}$ and thus a lower production of DOC in solution. This suggestion corroborates findings by Dighton (1978) who observed in incubation studies on the basis of daily $\mathrm{CO}_{2}$ measurements a positive relationship between the input of different amounts of honeydew sugars (saccharose and glucose) and the carbon mineralisation rate of organic material in soils. This phenomenon of a "priming action" describes an increase in rates of soil organic matter mineralisation due to an addition of fresh organic components.

The remarkable high $\mathrm{DOC}$ and $\mathrm{DNb}$ outputs from the Oa layer on September 21st at both forest sites, might be attributed to an extreme climatic event exhibiting high precipitation amounts and consequently higher fluxes of soil percolates (140 to $144 \mathrm{~lm}^{-2}$ time $^{-1}$ of rain corresponding to 75 to $78 \mathrm{~lm}^{-2}$ time $^{-1}$ of soil water fluxes), thus causing dilution effects of $\mathrm{C}$ and $\mathrm{N}$ in throughfall solutions and high mobilisation rates and thus fluxes in soil leachates. This observation might point to the fact, 
that extreme abiotic (hydrological) conditions may mask the effects of biotically-mediated processes among different ecosystem strata.

\section{Conclusion}

Our results indicated, that canopy herbivory significantly affect the (organic) matter release from and the transformation of $\mathrm{C}$ and $\mathrm{N}$ compounds within the canopy by their intensive but short-term defoliating activity. Under epidemic conditions, the source function of the canopy alters remarkably with respect to the qualitatively and quantitatively modified release of all $\mathrm{C}$ and $\mathrm{N}$ fractions. However, especially under mass outbreak situations the canopy appears rather as a sink for inorganic $\mathrm{N}$ species and presumably as a source for DON due to microbialmediated transformation processes. In conclusion, the population ecology of phytophagous insects allows partly to explain temporal-spatial alterations in nutrient cycling and thus ecosystem functioning (Schowalter 2000; Wardle, et al. 2000; Michalzik and Stadler 2005).

With regard to insect-mediated processes in both above- and belowground compartments of ecosystems the reasons for the observed soil flux pattern are not fully understood. Under extreme hydrological conditions, it seems, as if abiotic rather than biotic driving factors were responsible for the diverting flux pattern observed in the soil.

The study demonstrates the importance of linking the population and associated frass dynamics of herbivorous insects with the cycling of nutrients and organic matter in forest ecosystems, pinpointing the remarkable alterations in the timing, amounts and nature of organic matter dynamics on the ecosystem level.

Acknowledgements We gratefully acknowledge the valuable information on predicted herbivore infestation levels provided by Michael Habermann and Uwe Schmidt from the Forest Protection Unit of the NW-FVA (Northwest German Forest Research Station) in Göttingen and support by the forest ranger Harald Westermann (forest district Trochel). We are deeply indebted to Petra Voigt and Anja Soedje from the Laboratory Unit of the Institute of Geography at the University of Göttingen for chemical analyses and help during the study, and to Annett Reinhardt and Björn Geschwind for their great help in the field. Financial support was provided by the German Research Foundation (DFG, Project No. MI 927/1-3).
Open Access This article is distributed under the terms of the Creative Commons Attribution Noncommercial License which permits any noncommercial use, distribution, and reproduction in any medium, provided the original author(s) and source are credited.

\section{References}

Annila E, Långström $\mathrm{B}$, Varama $\mathrm{B}$, Hiukka $\mathrm{R}$, Niemela $\mathrm{P}$ (1999) Susceptibility of defoliated scots pine to spontaneous and induced attacks by Tomicus piniperda and Tomicus minor. Silva Fenn 33:93-106

Bergvist B, Folkeson L (1992) Soil acidification and element fluxes of a Fagus sylvatica forest as influenced by simulated nitrogen deposition. Water Air Soil Pollut 65:111-133

Brändle M, Brandl R (2001) Distribution, abundance and niche breadth: scale matters. Glob Ecol Biogeogr 10:173-177

Cedervind J, Pettersson M, Långström B (2003) Attack dynamics of the pine shoot beetle Tomicus piniperda (Col.: Scolytidae) in scots pine stands defoliated by Bupalus piniaria (Lep.: Geometridae). Agric For Entomol 3:253-261

Chapman SK, Hart SC, Cobb NS, Whitham TG, Koch GW (2003) Insect herbivory increases litter quality and decomposition: an extension of the acceleration hypothesis. Ecology 84:2867-2876

Dale VH, Joyce LA, McNulty S, Neilson RP, Ayres MP, Flannigan MD, Hanson PJ, Irland LC, Lugo AE, Peterson CJ, Simberloff D, Swanson FJ, Stocks BJ, Wotton BM (2001) Climate change and forest disturbances. Bioscience 51:723-734

Dighton J (1978) In vitro experiments simulating the possible fate of aphid honeydew sugars in soil. Soil Biol Biochem 10:53-57

Fonte SJ, Schowalter TD (2004) Decomposition of greenfall vs. senescent foliage in relation to herbivory and disturbance in a forest ecosystem. Biotropica 36:374-382

Frost CJ, Hunter MD (2004) Insect canopy herbivory and frass deposition affect soil nutrient dynamics and export in oak mesocosms. Ecology 85:3335-3347

Gauger T, Haenel HD, Rösemann C, Dämmgen U, Bleeker A, Erisman JW, Vermeulen AT, Schaap M, Timmermanns RMA, Builtjes PJH, Duyzer JH (2008) National Implementation of the UNECE Convention on Long-range Transboundary Air Pollution (Effects). Part 1: Deposition Loads: Methods, modelling and mapping results, trends. In: UBA-Texte Nr. 38(2008). Umweltbundesamt. DessauRosslau, Umweltbundesamt

Hartley SE, Jones TH (2004) Insect herbivores, nutrient cycling and plant productivity: a review. In: Weisser WW, Siemann E (eds) Insects and ecosystem function. Springer-Verlag, Springer Ecological Studies Series 137:27-52

Huberty AF, Denno RF (2004) Plant water stress and its consequences for herbivorous insects: a new synthesis. Ecology 85:1383-1398

Hunter MD (2001) Insect population dynamics meets ecosystem ecology: effects of herbivory on soil nutrient dynamics. Agric For Entomol 3:77-84 
Jactel H, Nicoll BC, Branco M, Gonzalez-Olabarria JR, Grodzki W, Långström B, Moreia F, Netherer S, Orazio C, Piou D, Santos H, Schelhaas MJ, Tojic K, Vodde F (2009) The influence of forest stand management on biotic and abiotic risks of damage. Ann For Sci 66:701, pp 18

Kreutzer K, Butterbach-Bahl K, Rennenberg H, Papen H (2009) The complete nitrogen cycle of an N-saturated spruce forest ecosystem. Plant Biol 11:643-649

Kurz WA, Dymond CC, Stinson G, Rampley GJ, Neilson ET, Carroll AL, Ebata T, Safranyik L (2008) Mountain pine beetle and forest carbon feedback to climate change. Nature 452:987-990

Långström B, Hellqvist C (1993) Induced and spontaneous attacks by pine shoot beetles on young Scots pine trees: tree mortality and beetle. J Appl Entomol 115:25-36

Långström B, Annila E, Hellqvist C, Varama M, Niemelä P (2001) Tree mortality, needle biomass recovery and growth losses in Scots pine following defoliation by Diprion pini and subsequent attack by Tomicus piniperda. Scand J For Res 16:342-353

Larsson S, Tenow O (1984) Areal distribution of a Neodirprion sertifer outbreak on Scots pine related to stand condition. Holarct Ecol 7:81-90

le Mellec A, Michalzik B (2008) Impact of a pine lappet (Dendrolimus pini) mass outbreak on $\mathrm{C}$ and $\mathrm{N}$ fluxes to the forest floor and soil microbial properties in a Scots pine forest in Germany. CJFR 38:1829-1849

le Mellec A, Habermann M, Michalzik B (2009) Canopy herbivory altering $\mathrm{C}$ to $\mathrm{N}$ ratios and soil input patterns of different organic matter fractions in a Scots pine forest. Plant and Soil 325:255-262

Lovett GM, Ruesink AE (1995) Carbon and nitrogen mineralization from decomposing gypsy moth frass. Oecol 104:133-138

Lovett GM, Christensen LM, Groffman PM, Jones GG, Hart EJ, Mitchell MJ (2002) Insect defoliation and nitrogen cycling in forests. Bioscience 52:335-341

Madritch MD, Hunter MD (2003) Intraspecific litter diversity and nitrogen deposition affect nutrient dynamics and soil respiration. Oecol 136:124-128
Mattson WJ, Haack RA (1987) The role of drought stress in provoking outbreaks of phytophagous insects. In: Barbosa P, Schultz JC (eds) Insect outbreaks. Academic, New York, pp 365-407

Michalzik B, Stadler B (2005) Importance of canopy herbivores to dissolved and particulate organic matter fluxes to the forest floor. Geoderma 127:227-236

Michalzik B, Kalbitz K, Park JH, Solinger S, Matzner E (2001) Fluxes and concentrations of dissolved organic carbon and nitrogen - a synthesis for temperate forests. Biogeochemistry 52:173-205

Parmesan C, Yohe G (2003) A globally coherent fingerprint of climate change impacts across natural systems. Nature 421:37-42

Piirainen S, Finér L, Starr M (1998) Canopy and soil retention of nitrogen deposition in a mixed boreal forest in eastern Finland. Water Air Soil Pollut 105:65-174

Qualls RG, Haines BL (1991) Geochemistry of dissolved organic nutrients in water percolating through a forest ecosystem. Soil Sci Soc Am J 52:1112-1123

Ritchie ME, Tilman D, Knops JMH (1998) Herbivore effects on plant and nitrogen dynamics in oak savanna. Ecology 79:165-177

Schowalter TD (2000) Insect ecology: an ecosystem approach. Academic, San Diego

Schowalter TD, Sabin TE, Stafford SG, Sexton JM (1991) Phytophage effects on primary production, nutrient turnover, and litter decomposition of young Douglas-fir in western Oregon. For Ecol Manage 42:229-243

Schwenke W (1962) Neue Erkenntnisse über Entstehung und Begegnung von Massenvermehrung an Kiefer-und Fichtennadeln fressender Insekten. Z angew Entomol 50:137-142

Stadler B, Michalzik B, Müller T (1998) Linking aphid ecology with nutrient fluxes in a coniferous forest. Ecology 79:1514-1525

Stadler B, Solinger S, Michalzik B (2001) Insect herbivores and the nutrient flow from the canopy to the soil in coniferous and deciduous forests. Oecologia 126:104-113

Wardle DA, Bonner KI, Barker GM (2000) Stability of ecosystem properties in response to above-ground functional group richness and composition. Oikos 89:11-23 